\title{
Utilization of Avocado and Mango Fruit Wastes in Multi-Nutrient Blocks for Goats Feeding: In Vitro Evaluation
}

\author{
Carlos Navarro Marcos ${ }^{1} \mathbb{1}$, María Dolores Carro ${ }^{1}{ }^{\circledR}$, Julia E. Fernández-Yepes ${ }^{2}$, Lesly Arbesu ${ }^{2}(\mathbb{D}$ \\ and Eduarda Molina-Alcaide $2, * \mathbb{D}$ \\ 1 Departamento de Producción Agraria, ETSIAAB, Universidad Politécnica de Madrid, Ciudad Universitaria, \\ 28040 Madrid, Spain; navarro-88@hotmail.com (C.N.M.); mariadolores.carro@upm.es (M.D.C.) \\ 2 Estación Experimental del Zaidín (Consejo Superior de Investigaciones Científicas), Profesor Albareda 1, \\ 18008 Granada, Spain; julia.fernandez@eez.csic.es (J.E.F.-Y.); leslyarbesu@gmail.com (L.A.) \\ * Correspondence: molina@eez.csic.es; Tel.: +34-910-671-023
}

Received: 7 November 2020; Accepted: 1 December 2020; Published: 3 December 2020

Simple Summary: The demand for animal products generated with high animal welfare standards and low environmental impact is continuously increasing. Moreover, the growing awareness of consumers about the importance of a healthy diet to reduce the prevalence of dietary illnesses has increased the consumption of vegetables and fruits, generating more vegetable wastes. Using these wastes in animal feeding would reduce the pollution caused by their accumulation, but their nutritive value needs to be assessed. We analyzed the chemical composition and in vitro ruminal fermentation of avocado and mango fruit wastes (peels and a pulp:peels (PP) mixture), and the potential of including the PP mixture into multi-nutrient blocks (MB) for goats feeding. Tested wastes had high-moisture content, but whereas those from mango were rich in non-structural carbohydrates, those from avocado had high fat content. Mango wastes were fermented at a greater extent and faster rate than avocado ones. Only subtle differences were observed in the fermentation of MB including $\mathrm{PP}$ from either avocado or mango. Using the PP mixture in MB for goats seems to be a viable solution to reduce the waste's environmental impact, but studies assessing the MB acceptance by the animals and their stability over long-time storage periods are needed.

\begin{abstract}
This study was conducted to investigate the nutritive value of avocado and mango fruit wastes, and to assess the possibility of preserving the wastes into multi-nutrient blocks (MB). Both peels and a pulp:peels (PP) mixture of each fruit were analyzed for chemical composition and in vitro fermentation with goats' ruminal fluid. Wastes had low-dry matter (DM) content $(<250 \mathrm{~g} / \mathrm{kg})$, with those from mango having high non-structural carbohydrates content $(>800 \mathrm{~g} / \mathrm{kg} \mathrm{DM})$ and those from avocado high fat levels ( $>580 \mathrm{~g} / \mathrm{kg} \mathrm{DM})$. Mango wastes were fermented at a greater extent and faster rate than avocado ones. The PP mixture of each fruit was included into multi-nutrient blocks (MB) formulated to have similar chemical composition. There were only subtle differences in the fermentation of $\mathrm{MB}$ including wastes from either avocado or mango, but fermentation of avocado-MB resulted in significantly $(p \leq 0.032)$ greater acetate and lower propionate proportions than mango-MB. Including the PP mixture in the formulation of MB for goats feeding is a feasible option to reduce the environmental impact of avocado and mango fruit wastes, but studies on the acceptance of the MB by goats and their stability over long-time storage periods are needed.
\end{abstract}

Keywords: peels; pulp; tropical fruits; preserving methods; ruminal fermentation; methane 


\section{Introduction}

The demand for tropical fruits, such as avocado and mango, has increased over the last years [1] because they exhibit a wide range of bioactive compounds beneficial for human health. Avocado is a tropical crop with more than 6 million tons produced annually [2], and its consumption is rapidly growing worldwide, especially in Europe [3]. Although much of avocado production is consumed fresh, many avocado food (drinks, guacamole, sauces, etc.) and cosmetic (shampoo, skin creams, oils, etc.) products are also available in the market. Avocado cultivation and processing generate large quantities of waste products, mainly peels and kernels, which represent between $18 \%$ and $13 \%$ of fruit fresh weight [4]. Mango is considered the most important tropical crop cultivated worldwide, and currently more than 46 million tons are produced annually [2], with high expectations of increasing production due to the increased consumer demand [5]. Mango fruits are consumed fresh, but they can also be processed (canned, juices and nectar, dehydrated fruit, frozen, etc.), and these processes generate high amounts of wastes, which are mainly composed of peels and kernels that can account for $35-60 \%$ of fruit fresh weight [5]. In the processing of both fruits, pulp is also originated as waste.

Utilization of agricultural wastes in animal feeding is a viable option to reduce the environmental impact associated to their management and to decrease the cost of animal feeding. In addition, including avocado and mango fruit wastes in animal diets could produce beneficial effects to the animals due to their bioactive compounds, such as polyphenols and tannins $[4,6]$. However, these wastes have high-moisture content, being highly perishable and prone to rapid spoilage [7]. Furthermore, the generation of these wastes is concentrated in the harvesting period. All these factors make the use of these wastes in animal feeding difficult, and low-cost preservation methods are required [7]. An interesting cost-effective preservation method, but still not widely used, is the inclusion of fruit wastes in multi-nutrient blocks (MB) [8], which are a solid mixture of feeds, urea, binder, salt and mineral and vitamin supplements [9]. The effects of feeding MB including avocado wastes to goats on milk yield and composition have been recently studied [10], but to our best knowledge, there is no information on the possibility of including mango wastes in MB. However, several studies have investigated the direct feeding of mango wastes to ruminants [11-13] and non-ruminants [14,15], indicating that they can be used as alternative feeds [16]. The aim of this study was therefore to assess the chemical composition and in vitro ruminal fermentation of two type of wastes from avocado and mango, peels and a mixture of pulp and peels (PP), and to analyze the in vitro ruminal fermentation of MB including PP wastes of each fruit.

\section{Materials and Methods}

\subsection{Avocado and Mango Fruit Wastes}

Avocado and mango fruits were collected from a local market in Granada (Spain). Fruits were first cleaned and carefully peeled. The peels were then cleaned of any flesh. The kernels from all fruits were extracted and they were discarded after the rest of the pulp was removed and mixed. The pulp of the fruit was mixed with that obtained from cleaning the peels and kernels and homogenized using an industrial mixer (SAMMIC S.L., Azkoitia, Spain). All parts of the fruits (peel, kernel and pulp) were weighed to state their relative proportions in the fruit. A portion of the pulp and peels were mixed up (on a weight basis) at a ratio of 81:19 for avocado and 65:35 for mango, representing their proportions in the fruit. All samples were stored frozen until analysis.

\subsection{Animals and Feeding}

All animals used in this study were cared for and handled in accordance with the Spanish guidelines for experimental animal protection (Royal Decree 53/2013 on the protection of animals used for experimentation or other scientific purposes). Procedures for rumen content sampling were approved by the Ethic Committee for Animal Experimentation of the Spanish Research Council and Junta de Andalucía (Approval number 22/06/2016/115). Three adult, dry, non-pregnant, rumen-fistulated 
Murciano-Granadina goats $(46.9 \pm 2.15 \mathrm{~kg}$ body weight) were housed individually and used as inoculum donors for the in vitro incubations. The internal diameter of the cannula was $4.5 \mathrm{~cm}$, which allows the collection of both liquid and solid fractions from different parts of the rumen. Goats were fed alfalfa hay twice a day at 9:00 and 18:00 $\mathrm{h}$ to meet energy maintenance requirements [17] and had free access to fresh water.

\subsection{Experimental Design}

This study comprised two different experiments in which the same methodology was used. The chemical composition and in vitro rumen fermentation of avocado and mango wastes was studied in Experiment 1, whereas Experiment 2 assessed the chemical composition and in vitro rumen fermentation of multi-nutrient blocks (MB) including either avocado (AMB) or mango wastes (MMB) and of mixed diets including MB and alfalfa hay. In both experiments, all feed samples were ground ( $1 \mathrm{~mm}$ screen) before chemical analysis and in vitro incubations.

\subsubsection{Experiment 1. In Vitro Fermentation of Avocado and Mango Fruit Wastes}

Batch cultures of ruminal microorganisms were used to assess the in vitro ruminal fermentation, $\mathrm{CH}_{4}$ production and kinetic of gas production of avocado and mango peels and a mixture of pulp and peels in a 81:19 and 65:35 ratio respectively, representing the proportions of each part in the fruit. The experimental procedure has been described in detail by Molina-Alcaide et al. [18]. Briefly, rumen content from each of the three goats was collected before the morning feeding, pooled, and immediately taken to the laboratory into thermal flasks. Rumen contents were strained through four layers of cheesecloth, and mixed (1:4 ratio) with the buffer solution described by Goering and Van Soest [19] (without adding trypticase). The procedure was conducted at $39{ }^{\circ} \mathrm{C}$ under continuous flushing with $\mathrm{CO}_{2}$.

Three identical $144 \mathrm{~h}$ incubation runs were carried out, and in each of them, 4 bottles per sample and 4 bottles without substrate (blanks) were used. In addition, two conventional feeds widely used in ruminant feeding (wheat middlings and corn grains) were included in the incubations to serve as reference. Four hundred $\mathrm{mg}$ of each sample were carefully weighed into $120 \mathrm{~mL}$ bottles before adding $48 \mathrm{~mL}$ of the buffered rumen fluid into each bottle. Bottles were sealed with rubber stoppers and aluminum caps, and incubated at $39{ }^{\circ} \mathrm{C}$ in a water bath. Two bottles for each sample and two blanks were used to assess the gas production kinetics of the samples. Both the pressure inside the bottle and the volume of gas produced were measured at 2, 4, 6, 8, 12, 24, 48, 72, 96, 120 and $144 \mathrm{~h}$ of incubation using a Wide-Range Pressure Meter (Sper Scientific LTD, Scottsdale, AZ, USA) and a glass-calibrated syringe (Ruthe ${ }^{\circledR}$, Normax, Marinha Grande, Portugal). At the end of the incubation period, fermentation was stopped by placing the bottles in iced-water. The content of the bottles was frozen, freeze-dried and analyzed for neutral detergent fiber (NDF) to calculate the true dry matter (DM) degradability (TDMD) [20].

The rest of the bottles ( 2 per sample and 2 blanks) were incubated for $24 \mathrm{~h}$ before measuring the volume of gas produced as described above. A gas sample $(10 \mathrm{~mL})$ was stored in an evacuated tube (Terumo Europe N.V., Leuven, Belgium) for analysis of $\mathrm{CH}_{4}$ concentration. The bottles were then uncapped, the $\mathrm{pH}$ was measured immediately (Crison Basic $20 \mathrm{pH}$-meter, Crisson Instruments, Barcelona, Spain) and the bottles were placed in iced-water. The following samples were then taken: $2 \mathrm{~mL}$ were mixed with $2 \mathrm{~mL}$ of deproteinizing solution $(20 \mathrm{~g}$ of metaphosphoric acid and $0.6 \mathrm{~g}$ of crotonic acid per 1) for volatile fatty acids (VFA) analysis, and $1 \mathrm{~mL}$ was preserved with $1 \mathrm{~mL}$ of $0.5 \mathrm{M}$ $\mathrm{HCl}$ for $\mathrm{NH}_{3}-\mathrm{N}$ analysis. Samples were immediately frozen $\left(-20{ }^{\circ} \mathrm{C}\right)$.

2.3.2. Experiment 2. In Vitro Fermentation of Multi-Nutrient Blocks (MB) Including Avocado and Mango Fruit Wastes and of Diets Based on Alfalfa Hay and MB

Two types of MB including the PP mixture, from either avocado or mango, used in Experiment 1 (AMB and $\mathrm{MMB}$, respectively), were formulated to have similar nitrogen $(\mathrm{N})$ and neutral detergent 
fiber (NDF) content. The feed ingredient composition of the MB is shown in Table 1. The MB were prepared following the methodology described by Molina-Alcaide et al. [8]. Briefly, all feed ingredients were thoroughly mixed and water was added before packing and hard-pressing the mixture into metal round molds. Finally, the MB were removed from the molds and air-dried outdoors before analysis of chemical composition and in vitro rumen fermentation. Additionally, 50:50 mixtures of alfalfa hay and either AMB or MMB (on fresh weight basis) were prepared to resemble mixed diets used for goats feeding in practical conditions.

Table 1. Ingredient composition $(\mathrm{g} / \mathrm{kg}$ fresh matter) of multi-nutrient blocks including a mixture of pulp and peels either from avocado tested in Experiment $2^{1}$.

\begin{tabular}{lcc}
\hline Ingredient & AMB $^{2}$ & MMB $^{3}$ \\
\hline Avocado pulp and peels & 150 & - \\
Mango pulp and peels & - & 290 \\
Sunflower meal & 250 & 258 \\
Wheat bran & 221 & 200 \\
Corn & 220 & 100 \\
Barley straw & 80.0 & 90.0 \\
Beet molasses & 49.5 & 21.0 \\
Quicklime & 20.0 & 20.0 \\
Urea & 4.1 & 4.0 \\
Palm soap & 0.4 & 12.0 \\
Vitamin-mineral mixture & 5.0 & 5.0 \\
\hline
\end{tabular}

1 The pulp:peels ratio (weight basis) in the mixture was 81:19 for avocado and 65:35 for mango; ${ }^{2}$ AMB: multinutrient blocks including a mixture of pulp and peels from avocado; ${ }^{3} \mathrm{MMB}$ : multinutrient blocks including a mixture of pulp and peels from mango.

Incubation procedures were as described in Experiment 1, and $\mathrm{AMB}, \mathrm{MMB}$, alfalfa hay:AMB and alfalfa hay:MMB mixtures at a 50:50 ratio were incubated. Alfalfa hay was also included as a reference feed. As in Experiment 1, three incubation runs were carried out using 4 bottles per sample, and 4 blanks in each of them. Sampling was as described in Experiment 1 for both 144 and $24 \mathrm{~h}$ incubations.

\subsection{Chemical Analyses}

Ground samples (1 mm) were analyzed for dry matter (ID 934.01), ash (ID 048.13) and ether extract (EE; ID 920.39) according to the methods of the Association of Official Analytical Chemists [21]. Analyses of total N, NDF, acid detergent fiber (ADF) and lignin were performed for samples of mango wastes and for defatted avocado wastes. Total $\mathrm{N}$ analysis was performed using a Leco TruSpec $\mathrm{CN}^{\circledR}$ (Leco Corporation, St. Joseph, MI, USA). The NDF, ADF and lignin were analyzed according to Van Soest et al. [22] using a Fiber Analyzer (ANKOM Model 220, ANKOM Technology Corporation, Fairport, NY, USA) and $\alpha$-amylase for NDF analyses. Both NDF and ADF contents were expressed exclusive of residual ash and without sulfite. An adiabatic calorimeter (Model 1356, Parr Instruments Co., Moline, IL, USA) was used to assess the energy content of the samples, and their content in non-structural carbohydrates (NSC) were calculated as (organic matter (OM)-crude protein-NDF-EE).

The $\mathrm{CH}_{4}$ concentration in the gas produced was determined by gas chromatography using a Hewlett HP 5890 Series II gas chromatograph (Hewlett Packard, Waldbronn, Germany) equipped with a flame ionization detector and a HP-INNOWAX crosslinked polyethylene glycol column $(25 \mathrm{~m} \times$ $0.2 \mathrm{~mm} \times 0.2 \mu \mathrm{m})$ and using He as carrier gas. A sample of $0.5 \mathrm{~mL}$ of the gas obtained from the bottles was injected using a $1 \mathrm{~mL}$ Hamilton gastight sample-lock ${ }^{\circledR}$ syringe (Hamilton, NV, USA). Total and individual volatile fatty acids (VFA) were analyzed by gas chromatography following the methodology described by Isaac et al. [23], and $\mathrm{NH}_{3}-\mathrm{N}$ concentrations were determined by a colorimetric method [24] 


\subsection{Calculations and Statistical Analyses}

The amount of gas produced in the blank bottles was used to correct the gas production values for the gas release from endogenous materials. The NLIN) procedure of SAS Institute [25] was used to adjust the gas values to the model of Krishnamoorthy et al. [26]: $\mathrm{y}=$ PGP $\left(1-\mathrm{e}^{(-c(\mathrm{t}-\operatorname{lag}))}\right)$, where $y$ is gas $(\mathrm{mL})$ measured at a sampling time $\mathrm{t}(\mathrm{h}), \mathrm{PGP}$ is the potential gas production (asymptote; $\mathrm{mL}), c$ is the fractional gas production rate $(\% / \mathrm{h})$ and lag $(\mathrm{h})$ is the delay in starting gas production. The gas production rate between the start of the incubation and the time at which $50 \%$ of PGP is reached (average gas production rate; AGPR; $\mathrm{ml} / \mathrm{h}$ ) was estimated as suggested by France et al. [27]: AGPR $=$ PGP $c /[2(\ln 2+c$ lag) $]$. Finally, the DM effective degradability (DMED) was estimated using the equation proposed by France et al. [27]: DMED $=\left[(\operatorname{TDMD} c) /\left(c+\mathrm{K}_{\mathrm{p}}\right)\right] \mathrm{e}^{(-\mathrm{kp} \text { lag })}$. A rumen particulate outflow $\left(\mathrm{K}_{\mathrm{p}}\right)$ value of $3.0 \% / \mathrm{h}$, corresponding to ruminants at moderate intake levels [28], was utilized to estimate DMED values.

The amount of VFA in the bottles' content after $24 \mathrm{~h}$ of incubation was corrected for the amount of VFA produced in the blanks. The proportion of minor VFA was calculated as the sum of isobutyrate, isovalerate and valerate.

Within each incubation run, the values measured in the two bottles incubated for each sample at each incubation time (144 or $24 \mathrm{~h}$ ) were averaged before statistical analysis, resulting in three replicates per sample. The PROC MIXED of SAS [25] was used for all statistical analyses. In Experiment 1, data were analyzed as a mixed model which included the fruit (avocado or mango), the fraction (either peels or the PP mixture) and their interaction as fixed effects and the inoculum (incubation run) as a random effect. In Experiment 2, data were also analyzed as a mixed model in which the type of $\mathrm{MB}(\mathrm{AMB}$ or $\mathrm{MMB})$, the diet (MB alone or with alfalfa hay) and their interaction were considered as fixed effects and the effect of inoculum was random. Statistical significance was set at $p<0.05$, and $p$ values $\geq 0.05$ and $\leq 0.10$ were considered as trends.

\section{Results and Discussion}

\subsection{Experiment 1. Chemical Composition and In Vitro Rumen Fermentation of Avocado and Mango} Fruit Wastes

The chemical composition of avocado and mango wastes and of the two feeds used as reference (wheat middlings and corn grains) is shown in Table 2. As indicated previously, the proportions of pulp and peels in the PP mixtures represented their relative percentages in the fruits (on fresh weight basis), and were 81:19 for avocado and 65:35 for mango. Similar proportions of both fractions had been reported for avocado [4], but lower proportion of peels (7\% to $24 \%$ ) than in the present study were observed for mango [5,29], which can be due to the use of different peeling procedures.

The results from the present study agree with previously reported results [30] as the wastes from both fruits had low DM content ( $<250 \mathrm{~g} / \mathrm{kg}$ fresh matter) and $\mathrm{N}(\leq 16.0 \mathrm{~g} / \mathrm{kg} \mathrm{DM})$. Both DM and $\mathrm{N}$ levels were greater in avocado (averaged values for analyzed wastes: $240 \mathrm{~g} \mathrm{DM} / \mathrm{kg}$ and $15.9 \mathrm{~g} \mathrm{~N} / \mathrm{kg}$ $\mathrm{DM}$, respectively) than in mango samples (191 $\mathrm{g} \mathrm{DM} / \mathrm{kg}$ and $6.10 \mathrm{~g} \mathrm{~N} / \mathrm{kg} \mathrm{DM})$. In accordance with previous results for mango [31,32], the peels contained more NDF and ADF than the PP mixture for both fruits. The peels from both fruits had similar NDF and ADF content, but the fiber from avocado peels was more lignified than that of mango peels (30.3 vs. $13.6 \mathrm{~g}$ lignin/100 $\mathrm{g}$ NDF). Negesse et al. [30] also reported similar content of both NDF and ADF in peels from avocado and mango, but the values reported by these authors were 2.2 times greater than those obtained in the present study. Chemical composition of avocado and mango fruits might vary depending on the fruit variety, cultivation conditions and ripeness, among other factors [4,33]. The high EE content in the avocado wastes agrees well with values from previously published studies [30,33], and explains the 1.7 times greater gross energy content of avocado wastes compared with mango wastes. Finally, the chemical composition of the two reference feeds was in the range of the values reported in the literature [34,35]. Both wheat 
middlings and corn grains are highly degradable in the rumen $[34,35]$, but differ widely in their $\mathrm{N}$ and NDF content.

As shown in Table 3, there were no fruit $\times$ fraction interactions in either the gas production or the fermentation parameters, except for $\mathrm{NH}_{3}-\mathrm{N}$ concentrations $(p=0.011)$ and $\mathrm{CH}_{4}$ production $(p=0.039)$, although trends $(p \leq 0.092)$ were observed for DMED, TDMD, minor VFA and $\mathrm{CH}_{4} / \mathrm{VFA}$ ratio. Both PGP and AGPR were greater $(p \leq 0.002)$ for mango than for avocado. The gas production technique is based on the positive relationship between the amount of gas produced and that of organic matter fermented [36], and the greater gas production for mango compared with avocado would indicate that mango wastes were fermented at a greater extent. Mango wastes are reported to be rich in easily fermentable and degradable compounds [37] whose fermentation contributes significantly to gas production. In fact, the amount of NSC in mango reached 810 and $828 \mathrm{~g} / \mathrm{kg}$ DM for peels and the PP mixture, respectively. The lack of lag time for any waste is indicative of a rapid start of fermentation.

As previously discussed by Marcos et al. [38], the gas production of high-EE samples should be interpreted with caution because ruminal fermentation of fat generates no gas, and fat can even reduce gas production due to the decreased $\mathrm{CH}_{4}$ [39]. In fact, $\mathrm{CH}_{4}$ production was lower $(p<0.001)$ for avocado than for mango samples, possibly due to the high EE content in avocado. The lack of differences $(p=0.513)$ between fruits in the $\mathrm{CH}_{4} / \mathrm{VFA}$ ratio suggests that the lower $\mathrm{CH}_{4}$ production observed for avocado compared to mango was due to the reduced fermentation of avocado, possibly caused by its high EE content. Unsaturated free fatty acids are toxic to fibrolytic bacteria [40] and avocado fat is rich in unsaturated fatty acids, usually accounting for more than $85 \%$ of total fatty acids $[10,41]$.

The trend for lower $(p \leq 0.073)$ values of DMED and TDMD for avocado (548 and $808 \mathrm{~g} / \mathrm{kg} \mathrm{DM}$, respectively; averaged values for peels and PP mixture) compared to mango (609 and $889 \mathrm{~g} / \mathrm{kg} \mathrm{DM}$ ) supports the differences between both fruits observed in gas production parameters. Skenjana et al. [42] reported similar DMED values $(529 \mathrm{~g} / \mathrm{kg} \mathrm{DM})$ for avocado meal estimated for a rumen particulate outflow of $0.05 / \mathrm{h}$. In contrast, Eliyahu et al. [7] and Negesse et al. [30] reported lower in vitro OM digestibility values for avocado pulp ( $300 \mathrm{~g} / \mathrm{kg}$ ) and peels $(365 \mathrm{~g} / \mathrm{kg})$, which were attributed to the high EE and lignin content in the avocado samples. Discrepancies among studies might be related to differences in the chemical composition of the wastes, as the avocado peels from the study of Negesse et al. [30] had greater NDF and lignin content (261 and $121 \mathrm{~g} / \mathrm{kg} \mathrm{DM}$, respectively) than the samples used in our study ( $\leq 115$ and $34.8 \mathrm{~g} / \mathrm{kg}$ DM, respectively). Our DMED values for mango wastes agree well with those of Sanon et al. [43], who reported a value of $610 \mathrm{~g} / \mathrm{kg}$ for DM digestibility of mango peels. In contrast, Negesse et al. [30] reported a greater value $(706 \mathrm{~g} / \mathrm{kg})$ for OM digestibility of mango peels estimated from an equation involving gas production and chemical composition. The high TDMD values obtained for mango wastes in our study $(\geq 882 \mathrm{~g} / \mathrm{kg})$ are in accordance with previously reported values ranging from 840 to $970 \mathrm{~g} / \mathrm{kg} \mathrm{DM}[44,45]$. 
Table 2. Chemical composition (g/kg dry matter (DM) unless otherwise stated) of the avocado and mango wastes, and conventional feeds tested in Experiment 1.

\begin{tabular}{|c|c|c|c|c|c|c|c|c|c|c|}
\hline Sample & $\begin{array}{c}\text { DM } \\
\text { (g/kg Fresh } \\
\text { Matter) }\end{array}$ & $\begin{array}{l}\text { Organic } \\
\text { Matter } \\
\text { (OM) }\end{array}$ & $\begin{array}{l}\text { Nitrogen } \\
\text { (N) }\end{array}$ & $\begin{array}{c}\text { Neutral } \\
\text { Detergent } \\
\text { Fiber (NDF) }\end{array}$ & $\begin{array}{c}\text { Acid } \\
\text { Detergent } \\
\text { Fiber (ADF) }\end{array}$ & $\begin{array}{c}\text { Acid } \\
\text { Detergent } \\
\text { Lignin }\end{array}$ & $\begin{array}{c}\text { Ether } \\
\text { Extract (EE) }\end{array}$ & Lignification $^{1}$ & $\begin{array}{c}\text { Non-Structural } \\
\text { Carbohydrates } \\
\text { (NSC) }^{2}\end{array}$ & $\begin{array}{l}\text { Gross } \\
\text { Energy } \\
(\mathrm{MJ} / \mathrm{kg})\end{array}$ \\
\hline \multicolumn{11}{|l|}{ Avocado and mango wastes ${ }^{3}$} \\
\hline Avocado peels & 236 & 981 & 15.8 & 115 & 104 & 34.8 & 589 & 30.3 & 182 & 30.5 \\
\hline Avocado pulp:peels mixture & 244 & 982 & 16.0 & 89.8 & 63.1 & 3.97 & 638 & 4.41 & 184 & 30.9 \\
\hline Mango peels & 208 & 974 & 5.13 & 118 & 95.1 & 16.0 & 13.9 & 13.6 & 810 & 18.0 \\
\hline Mango pulp:peels mixture & 174 & 975 & 7.07 & 95.5 & 63.5 & 11.3 & 7.34 & 11.8 & 828 & 17.5 \\
\hline \multicolumn{11}{|l|}{ Conventional feeds } \\
\hline Corn grains & 881 & 988 & 15.0 & 154 & 30.4 & 3.28 & 41.9 & 2.13 & 699 & 18.9 \\
\hline Wheat middlings & 886 & 964 & 28.3 & 372 & 111 & 23.7 & 37.8 & 6.37 & 377 & 19.4 \\
\hline
\end{tabular}

${ }^{1}$ Calculated as [(lignin/NDF) $\left.\times 100\right] ;{ }^{2}$ Calculated as $(\mathrm{OM}-(\mathrm{N} \times 6.25)-\mathrm{NDF}-\mathrm{EE}){ }^{3}$ The pulp:peels ratio (weight basis) in the mixture was $81: 19$ for avocado and $65: 35$ for mango. 
Table 3. Gas production parameters, dry matter (DM) effective degradability (DMED) and true DM digestibility (TDMD) in $144 \mathrm{~h}$ incubations and fermentation parameters in $24 \mathrm{~h}$ incubations of avocado and mango wastes (either peels or a pulp:peels mixture) and two reference feeds (corn grains and wheat middling) with buffered ruminal fluid from goats (Experiment 1).

\begin{tabular}{|c|c|c|c|c|c|c|c|c|c|c|}
\hline \multirow[b]{2}{*}{ Parameter } & \multicolumn{2}{|c|}{ Avocado } & \multicolumn{2}{|c|}{ Mango } & \multirow[b]{2}{*}{ SEM $^{1}$} & \multicolumn{3}{|c|}{$p=$} & \multirow[b]{2}{*}{ Corn Grains } & \multirow{2}{*}{$\begin{array}{l}\text { Wheat } \\
\text { Middlings }\end{array}$} \\
\hline & Peels & $\begin{array}{l}\text { Pulp:Peels } \\
(81: 19 w / w)\end{array}$ & Peels & $\begin{array}{l}\text { Pulp:Peels } \\
(65: 35 w / w)\end{array}$ & & Fruit & Fraction & $\begin{array}{c}\text { Fruit } \times \\
\text { Fraction }\end{array}$ & & \\
\hline \multicolumn{11}{|l|}{ Gas production parameters $^{2}$} \\
\hline PGP $(\mathrm{mL})$ & 60.7 & 56.5 & 156 & 153 & 2.30 & $<0.001$ & 0.215 & 0.809 & 157 & 123 \\
\hline$c($ per h) & 5.18 & 7.56 & 6.04 & 7.21 & 0.474 & 0.628 & 0.033 & 0.292 & 4.32 & 8.12 \\
\hline $\operatorname{lag}(\mathrm{h})$ & 0.00 & 0.00 & 0.00 & 0.00 & - & - & - & - & 1.62 & 0.00 \\
\hline AGPR (mL/h) & 2.27 & 3.08 & 6.77 & 7.91 & 0.464 & 0.002 & 0.126 & 0.746 & 4.46 & 7.20 \\
\hline $\operatorname{DMED}(\mathrm{g} / \mathrm{kg} \mathrm{DM})^{3}$ & 470 & 626 & 598 & 619 & 21.3 & 0.065 & 0.026 & 0.051 & 50.6 & 56.8 \\
\hline $\operatorname{TDMD}(\mathrm{g} / \mathrm{kg} \mathrm{DM})^{4}$ & 742 & 874 & 895 & 882 & 29.8 & 0.073 & 0.140 & 0.092 & 919 & 780 \\
\hline \multicolumn{11}{|c|}{ Fermentation parameters } \\
\hline $\mathrm{pH}$ & 6.79 & 6.80 & 6.45 & 6.42 & 0.031 & $<0.001$ & 0.841 & 0.558 & 6.56 & 6.68 \\
\hline $\begin{array}{l}\text { Total volatile fatty acids (VFA; } \\
\mathrm{mmol} / \mathrm{vial})\end{array}$ & 1.20 & 1.20 & 2.49 & 2.76 & 0.111 & $<0.001$ & 0.317 & 0.327 & 2.33 & 2.21 \\
\hline \multicolumn{11}{|l|}{ Individual VFA (mol/100 mol) } \\
\hline Acetate $(\mathrm{Ac})$ & 69.1 & 63.4 & 58.3 & 57.2 & 1.30 & 0.007 & 0.078 & 0.181 & 52.1 & 58.8 \\
\hline Propionate (Pr) & 24.0 & 26.5 & 29.3 & 30.4 & 1.88 & 0.092 & 0.403 & 0.740 & 27.3 & 27.4 \\
\hline Butyrate & 7.12 & 9.05 & 11.9 & 11.8 & 0.778 & 0.017 & 0.328 & 0.281 & 18.8 & 11.2 \\
\hline Minor VFA $^{5}$ & 0.431 & 1.06 & 0.513 & 0.649 & 0.0826 & 0.138 & 0.019 & 0.058 & 1.80 & 2.53 \\
\hline Acetate/Propionate $(\mathrm{mol} / \mathrm{mol})$ & 2.90 & 2.39 & 2.01 & 1.89 & 0.207 & 0.043 & 0.224 & 0.422 & 1.96 & 2.17 \\
\hline $\mathrm{NH}_{3}-\mathrm{N}(\mathrm{mg} / 100 \mathrm{~mL})$ & 6.58 & 14.6 & 1.40 & 0.97 & 0.746 & 0.001 & 0.015 & 0.011 & 1.75 & 13.5 \\
\hline $\mathrm{CH}_{4}(\mathrm{ml} / \mathrm{g}$ DM incubated $)$ & 30.7 & 31.1 & 68.2 & 61.5 & 1.01 & $<0.001$ & 0.052 & 0.039 & 67.6 & 57.6 \\
\hline $\mathrm{CH}_{4} / \mathrm{VFA}(\mathrm{mL} / \mathrm{mmol})$ & 10.2 & 10.4 & 11.0 & 8.95 & 0.42 & 0.513 & 0.105 & 0.083 & 11.6 & 10.4 \\
\hline
\end{tabular}

${ }^{1}$ SEM: standard error of the mean; ${ }^{2}$ PGP: potential gas production; $c$ : fractional rate of gas production; lag: delay until starting gas production; AGPR: average gas production rate;

${ }^{3}$ DMED: Dry matter effective degradability for a rumen particulate outflow of $3.0 \% / \mathrm{h} ;{ }^{4}$ True dry matter degradability calculated according to Van Soest et al. [20]; ${ }^{5}$ Sum of isobutyrate,

isovalerate and valerate. 
The lower $(p<0.001) \mathrm{pH}$ of mango compared with avocado samples agrees well with the greater $(p<0.001)$ total VFA production of mango wastes, because $\mathrm{pH}$ declines as VFA are produced and accumulated into the bottles. There were also differences between fruits in the VFA profile, and mango produced less $(p=0.007)$ acetate and more $(p=0.017)$ butyrate proportions than avocado wastes, and tended to greater $(p=0.092)$ propionate proportions than avocado. As a consequence, the acetate/propionate ratio was lower $(p=0.043)$ for mango, indicating a more efficient fermentation [46]. Differences in VFA profile are most likely related to the different carbohydrates' composition in each fruit. The greater $(p=0.001) \mathrm{NH}_{3}-\mathrm{N}$ concentrations of avocado compared with mango wastes are in accordance with the 2.6 times greater $\mathrm{N}$ content of avocado. As discussed by de Evan et al. [47], in vitro $\mathrm{NH}_{3}-\mathrm{N}$ concentrations are difficult to interpret, as they reflect the balance between the $\mathrm{NH}_{3}-\mathrm{N}$ produced by protein degradation and the $\mathrm{NH}_{3}-\mathrm{N}$ captured by the ruminal microorganisms for microbial protein synthesis. The high fermentation of mango wastes probably stimulated microbial growth, resulting in high $\mathrm{NH}_{3}-\mathrm{N}$ capture by the microorganisms and low $\mathrm{NH}_{3}-\mathrm{N}$ concentrations, which were below the level of $5 \mathrm{mg}$ of $\mathrm{NH}_{3}-\mathrm{N} / 100 \mathrm{~mL}$ recommended for optimal growth of ruminal microorganisms in vitro [48]. These results indicate that supplementation of mango wastes with $\mathrm{N}$ sources might improve their ruminal fermentation.

There were differences between wastes (peels and PP mixture) in some of the parameters analyzed. The greater $(p \leq 0.033) c$ and DMED values observed for the PP mixture compared to the peels indicate that pulp was fermented faster than peels for both fruits, as previously reported [49]. In contrast, the extent of ruminal degradation of both wastes was similar, as indicated by the lack of differences in the PGP and TDMD. The VFA profile was similar for both wastes excepting that the proportion of minor VFA was greater $(p=0.019)$ for the PP mixture than for the peels, with the difference greater for avocado than for mango (2.5 and 1.3 times greater, respectively). The greater proportion of minor VFA in the PP mixture of avocado compared with avocado peels is consistent with the greater $\mathrm{NH}_{3}-\mathrm{N}$ concentrations observed for the PP mixture, as both minor VFA and $\mathrm{NH}_{3}-\mathrm{N}$ are final products of protein degradation in the rumen, with isobutyrate and isovalerate being breakdown products of valine and leucine, respectively [45]. Because both the peels and the PP mixture had similar N content, these results might indicate that the protein of the PP mixture was more degradable than peel protein. This could be related to the presence of lower amounts of tannins in the peels than in the PP mixture [49], as tannins can form insoluble complexes with proteins and reduce their degradation [50]. Unfortunately, tannins content was not analyzed in the present study.

\subsection{Experiment 2. In Vitro Fermentation of Multi-Nutrient Blocks (MB) Including Avocado and Mango Fruit Wastes}

Table 4 shows the chemical composition of the feeds and diets used in Experiment 2. Dry matter content of both MB was high ( $\geq 905 \mathrm{~g} / \mathrm{kg}$ ). Although the MB were formulated to have similar $\mathrm{N}$ and fiber content, N, NDF and ADF levels were slightly greater in MMB compared with AMB. The more marked difference between the two MB types was in EE content, which was 1.8 times greater for AMB than for MMB; however, the fat level in both MB was below the maximal level of $60 \mathrm{~g} / \mathrm{kg}$ diet DM generally recommended to avoid negative effects on fiber digestibility [34]. The two mixed diets including the $\mathrm{MB}$ ( $\mathrm{AMB}$ and $\mathrm{MMB}$ ) had similar chemical composition, with the exception of EE content, that was 1.4 times greater for the diet containing AMB than for that including MMB.

Table 5 shows the parameters of gas production kinetics and the main fermentation parameters for both types of $M B$, the two mixed diets and the alfalfa hay included in the mixed diets. There were no interactions $(p \geq 0.122)$ between the MB type and the fermentation substrate (MB alone or in mixed diets including alfalfa hay) in any of the parameters measured, indicating that the effect of mixing the MB with alfalfa hay on fermentation parameters was similar for both AMB and MMB. The only difference between MB in the gas kinetics parameters was detected in the PGP, which was greater $(p=0.010)$ for AMB than for MMB. However, the difference was low $(105$ and $99 \mathrm{~mL}$ gas/g DM incubated for avocado and mango, respectively; averaged values for MB incubated alone and mixed diets), and probably 
not relevant in practice. These results indicate that avocado fat had no negative effect on the in vitro fermentation of $\mathrm{AMB}$ when used in the given levels.

Compared with AMB, the fermentation of MMB tended to show greater $(p=0.096) \mathrm{pH}$ values, which is consistent with the trend of lower VFA production $(p=0.054 ; 1.87$ and $1.77 \mathrm{mmol} / 400 \mathrm{mg}$ of $\mathrm{DM}$ ) for $\mathrm{AMB}$ and $\mathrm{MMB}$, respectively; averaged values for $\mathrm{MB}$ and mixed diets). Both $\mathrm{MB}$ differed in the VFA profile, as the fermentation of MMB resulted in greater $(p \leq 0.022)$ acetate proportions and acetate:propionate ratio, as well as in lower $(p=0.032)$ propionate proportion, than AMB fermentation. In contrast, $\mathrm{NH}_{3}-\mathrm{N}$ concentrations, $\mathrm{CH}_{4}$ production and $\mathrm{CH}_{4} /$ total VFA ratio were similar for both MBs. The observed differences between MB in VFA production and profile are due not only to the characteristics of the PP mixture included in each MB, but also to the use of variable proportions of other feed ingredients in the MB. The proportions of the PP mixture from avocado and mango in the MB were different due to the high EE content of the avocado PP mixture, which precluded its inclusion at greater levels.

The changes in gas production and fermentation parameters observed when MB were included in mixed diets are in accordance with the fermentation pattern of alfalfa hay (Table 5). Compared with the fermentation of $\mathrm{MB}$ as the only substrate, their 1:1 mixture with alfalfa hay resulted in lower PGP $(p=0.018)$ and tended to lower TDMD $(p=0.058)$, which is consistent with the reduced values of these parameters observed for alfalfa hay compared with MB. In contrast, mixed diets had greater $c$, AGPR and DMED values compared with MB, as a result of the greater values observed for alfalfa hay. The larger values of VFA production, acetate proportion and acetate:propionate ratio measured for the mixed diets compared to $\mathrm{MB}$ are in accordance with the high rumen fermentability of the alfalfa hay used in this study, as indicated by its high values of $c$, AGPR and DMED values, low NDF proportion and high $\mathrm{N}$ content. 
Table 4. Chemical composition (g/kg dry matter (DM) unless otherwise stated) of multi-nutrient blocks containing avocado (AMB) and mango (MMB) wastes, mixed diets composed of 1:1 alfalfa hay and multi-nutrient blocks, and alfalfa hay tested in Experiment 2.

\begin{tabular}{|c|c|c|c|c|c|c|c|c|c|c|}
\hline Sample & $\begin{array}{c}\text { DM } \\
\text { (g/kg Fresh } \\
\text { Matter) }\end{array}$ & $\begin{array}{c}\text { Organic } \\
\text { Matter } \\
\text { (OM) }\end{array}$ & $\begin{array}{l}\text { Nitrogen } \\
(\mathbf{N})\end{array}$ & $\begin{array}{c}\text { Neutral } \\
\text { Detergent } \\
\text { Fiber (NDF) }\end{array}$ & $\begin{array}{c}\text { Acid } \\
\text { Detergent } \\
\text { Fiber (ADF) }\end{array}$ & $\begin{array}{c}\text { Acid } \\
\text { Detergent } \\
\text { Lignin }\end{array}$ & $\begin{array}{c}\text { Ether } \\
\text { Extract (EE) }\end{array}$ & Lignification $^{1}$ & $\begin{array}{c}\text { Non-structural } \\
\text { Carbohydrates } \\
\text { (NSC) }^{2}\end{array}$ & $\begin{array}{l}\text { Gross } \\
\text { Energy } \\
(\mathrm{MJ} / \mathrm{kg})\end{array}$ \\
\hline \multicolumn{11}{|c|}{$\begin{array}{l}\text { Multi-nutrient blocks and feed } \\
\text { mixtures }\end{array}$} \\
\hline $\mathrm{AMB}^{3}$ & 915 & 921 & 32.2 & 413 & 246 & 94.3 & 43.5 & 22.8 & 263 & 18.7 \\
\hline $\mathrm{MMB}^{4}$ & 905 & 912 & 35.0 & 454 & 289 & 103 & 24.3 & 22.7 & 215 & 18.3 \\
\hline AMB: alfalfa hay & 907 & 903 & 32.2 & 434 & 302 & 92.5 & 33.3 & 21.3 & 235 & 18.1 \\
\hline $\begin{array}{l}\text { MMB: alfalfa hay } \\
\text { Other feeds }\end{array}$ & 925 & 898 & 33.6 & 457 & 325 & 96.2 & 24.1 & 21.1 & 207 & 17.9 \\
\hline Alfalfa hay & 889 & 884 & 32.1 & 458 & 360 & 89.4 & 23.7 & 19.5 & 202 & 17.5 \\
\hline
\end{tabular}

${ }^{1}$ Calculated as [(lignin/NDF) $\left.\times 100\right] ;{ }^{2}$ Calculated as $(\mathrm{OM}-(\mathrm{N} \times 6.25)-\mathrm{NDF}-\mathrm{EE}){ }^{3}$ AMB: multi-nutrient block containing a $81: 19(w / w)$ mixture of avocado pulp and peels; ${ }^{4} \mathrm{MMB}:$ multi-nutrient block containing a 65:35 (w/w) mixture of mango pulp and peels. Feed ingredient composition of AMB and MMB is given in Table 1. 
Table 5. Gas production parameters, dry matter effective degradability (DMED) and true dry matter digestibility (TDMD) in $144 \mathrm{~h}$ incubations and fermentation parameters in $24 \mathrm{~h}$ incubations of multi-nutrient blocks containing avocado (AMB) or mango (MMB) wastes (pulp:peels) incubated either alone or mixed 1:1 with alfalfa hay with buffered ruminal fluid from goats (Experiment 2).

\begin{tabular}{|c|c|c|c|c|c|c|c|c|c|}
\hline \multirow[b]{2}{*}{ Parameter } & \multicolumn{2}{|c|}{ AMB } & \multicolumn{2}{|c|}{ MMB } & \multirow[b]{2}{*}{ SEM $^{1}$} & \multicolumn{3}{|c|}{$p=$} & \multirow[b]{2}{*}{ Alfalfa Hay } \\
\hline & Alone & Mixed Diet & Alone & Mixed Diet & & $\mathrm{MB}^{2}$ & $\begin{array}{c}\text { Fermentation } \\
\text { Substrate }\end{array}$ & $\begin{array}{c}\mathrm{MB} \times \\
\text { Fermentation } \\
\text { Substrate }\end{array}$ & \\
\hline \multicolumn{10}{|l|}{ Gas production parameters ${ }^{3}$} \\
\hline PGP $(\mathrm{mL})$ & 108 & 101 & 99.8 & 97.2 & 1.02 & 0.010 & 0.018 & 0.122 & 91.0 \\
\hline$c($ per h) & 4.76 & 6.29 & 4.68 & 6.43 & 0.110 & 0.788 & $<0.001$ & 0.384 & 7.21 \\
\hline $\operatorname{lag}(\mathrm{h})$ & 0 & 0 & 0 & 0 & - & - & - & - & 0.00 \\
\hline AGPR (mL/h) & 3.71 & 4.58 & 3.37 & 4.51 & 0.101 & 0.131 & 0.002 & 0.279 & 4.73 \\
\hline DMED (g/kg DM $)^{4}$ & 443 & 483 & 450 & 474 & 8.2 & 0.952 & 0.030 & 0.413 & 486 \\
\hline $\operatorname{TDMD}(\mathrm{g} / \mathrm{kg} \mathrm{DM})^{5}$ & 723 & 713 & 739 & 696 & 8.8 & 0.942 & 0.058 & 0.154 & 688 \\
\hline \multicolumn{10}{|l|}{ Fermentation parameters } \\
\hline $\mathrm{pH}$ & 6.76 & 6.80 & 6.82 & 6.85 & 0.024 & 0.096 & 0.215 & 0.775 & 6.79 \\
\hline $\begin{array}{l}\text { Total volatile fatty acids (VFA; } \\
\mathrm{mmol} / 400 \mathrm{mg} \mathrm{DM} \text { ) }\end{array}$ & 1.83 & 1.90 & 1.70 & 1.84 & 0.030 & 0.054 & 0.042 & 0.301 & 1.88 \\
\hline \multicolumn{10}{|l|}{ Individual VFA (mol/100 mol) } \\
\hline Acetate $(\mathrm{Ac})$ & 60.4 & 65.0 & 62.2 & 66.3 & 0.31 & 0.015 & 0.001 & 0.451 & 68.9 \\
\hline Propionate (Pr) & 27.7 & 24.2 & 25.5 & 22.9 & 0.47 & 0.032 & 0.008 & 0.386 & 22.2 \\
\hline Butyrate & 10.0 & 7.96 & 10.2 & 7.87 & 0.344 & 0.904 & 0.008 & 0.721 & 5.37 \\
\hline Minor VFA $^{6}$ & 1.73 & 2.82 & 2.12 & 2.93 & 0.090 & 0.069 & 0.002 & 0.218 & 3.53 \\
\hline Acetate/Propionate $(\mathrm{mol} / \mathrm{mol})$ & 2.18 & 2.68 & 2.45 & 2.89 & 0.055 & 0.022 & 0.003 & 0.623 & 3.11 \\
\hline $\mathrm{NH}_{3}-\mathrm{N}(\mathrm{mg} / 100 \mathrm{~mL})$ & 14.9 & 15.3 & 17.7 & 17.3 & 1.05 & 0.104 & 0.998 & 0.729 & 18.8 \\
\hline $\mathrm{CH}_{4}(\mathrm{ml} / \mathrm{g}$ dry matter incubated) & 50.7 & 52.0 & 47.8 & 49.1 & 2.64 & 0.356 & 0.656 & 0.995 & 47.5 \\
\hline $\mathrm{CH}_{4} / \mathrm{VFA}(\mathrm{mL} / \mathrm{mmol})$ & 11.1 & 11.0 & 11.3 & 10.7 & 0.62 & 0.911 & 0.616 & 0.757 & 10.1 \\
\hline
\end{tabular}

${ }^{1}$ SEM: standard error of the mean; ${ }^{2}$ MB: multi-nutrient block; ${ }^{3}$ PGP: potential gas production; $c$ : fractional rate of gas production; lag: delay until starting gas production; AGPR: average

gas production rate; ${ }^{4}$ DMED: Dry matter effective degradability for a rumen particulate outflow of $3.0 \% / \mathrm{h} ;{ }^{5}$ True dry matter degradability calculated according Van Soest et al. [20];

6 Sum of isobutyrate, isovalerate and valerate. 


\section{Conclusions}

Both peels and pulp from avocado and mango had high-moisture content, but fiber content was greater in the peels than in pulp for both fruits. Mango fruit wastes were rich in non-structural carbohydrates, whereas those from avocado had high fat content, which reduced their ruminal fermentability. The inclusion of a pulp:peels mixture of either avocado or mango replacing conventional feeds in multi-nutrient blocks resulted in normal in vitro ruminal fermentation patterns, and therefore it might be a viable solution to feed ruminants and reduce the environmental impact of these wastes and animal feeding costs. Moreover, the inclusion of the multi-nutrient blocks in mixed diets with alfalfa hay as forage increased the fermentation rate of the diet. Additional studies are needed to assess the acceptance of the studied multi-nutrient blocks by ruminants and their stability over long-time storage periods.

Author Contributions: Conceptualization, E.M.-A.; investigation, C.N.M., J.E.F.-Y., L.A. and E.M.-A.; resources, E.M.-A. and M.D.C.; supervision, E.M.-A.; project administration, E.M.-A. and M.D.C.; funding acquisition, E.M.-A. and M.D.C.; formal analysis, C.N.M.; writing-original draft preparation, C.N.M.; writing-review and editing, E.M.-A. and M.D.C. All authors have read and agreed to the published version of the manuscript.

Funding: This work was supported by the Junta de Andalucía (Project P12-AGR-587) and by the Spanish State Research Agency (AEI) and the European Regional Development Fund (Project AGL2016-75322-C2-1-R).

Conflicts of Interest: The authors declare no conflict of interest.

\section{References}

1. Ramos-Aguilar, A.L.; Ornelas-Paz, J.; Tapia-Vargas, L.M.; Ruiz-Cruz, S.; Gardea-Béjar, A.A.; Yahia, E.M.; Ornelas-Paz, J.J.; Pérez-Martínez, J.D.; Rios-Velasco, C.; Ibarra Junquera, V. The importance of the bioactive compounds of avocado fruit (Persea americana Mill) on human health. Biotecnia 2019, 21, 154-162. [CrossRef]

2. FAOSTAT. Food and Agriculture Organization of the United Nations, Rome, Italy. 2017. Available online: http://www.fao.org/faostat/en/\#data/QC (accessed on 6 November 2020).

3. Migliore, G.; Farina, V.; Tinervia, S.; Matranga, G.; Schifani, G. Consumer interest towards tropical fruit: Factors affecting avocado fruit consumption in Italy. Agri. Food Econ. 2017, 5, 24-36. [CrossRef]

4. Wang, W.; Bostic, T.R.; Gu, L. Antioxidant capacities, procyanidins and pigments in avocados of different strains and cultivars. Food Chem. 2010, 122, 1193-1198. [CrossRef]

5. Jahurul, M.H.A.; Zaidul, I.S.M.; Ghafoor, K.; Al-Juhaimi, F.Y.; Nyam, K.-L.; Norulaini, N.A.N.; Sahena, F.; Omar, A.K.M. Mango (Mangifera indica L.) by-products and their valuable components: A review. Food Chem. 2015, 183, 173-180. [CrossRef]

6. Kim, H.; Moon, J.Y.; Kim, H.; Lee, D.-S.; Cho, M.; Choi, H.-K.; Kim, Y.S.; Mosaddik, A.; Cho, S.M. Antioxidant and antiproliferative activities of mango (Mangifera indica L.) flesh and peel. Food Chem. 2010, 121, 429-436. [CrossRef]

7. Eliyahu, D.; Yosef, E.; Weinberg, Z.G.; Hen, Y.; Nikbachat, M.; Solomon, R.; Mabjeesh, S.J.; Miron, J. Composition, preservation and digestibility by sheep of wet by-products from the food industry. Anim. Feed Sci. Technol. 2015, 207, 1-9. [CrossRef]

8. Molina-Alcaide, E.; Morales-García, E.Y.; Martín-García, A.I.; Ben Salem, H.; Nefzaoui, A.; SanzSampelayo, M.R. Effects of partial replacement of concentrate with feed blocks on nutrient utilization, microbial N flow, and milk yield and composition in goats. J. Dairy Sci. 2010, 93, 2076-2087. [CrossRef]

9. Ben-Salem, H.; Nefzaoui, A. Feed blocks as alternative supplements for sheep and goats. Small Rumin. Res. 2003, 49, 275-288. [CrossRef]

10. De Evan, T.; Carro, M.D.; Yepes, J.E.F.; Haro, A.; Arbesú, L.; Romero-Huelva, R.; Molina-Alcaide, E. Effects of Feeding Multinutrient Blocks Including Avocado Pulp and Peels to Dairy Goats on Feed Intake and Milk Yield and Composition. Animals 2020, 10, 194. [CrossRef]

11. Sruamsiri, S.; Silman, P. Nutritive value and nutrient digestibility of ensiled mango by-products. Maejo Int. J. Sci. Technol. 2009, 3, 371-378.

12. Sanon, H.O.; Kanwe, A.B.; Millogo, A.; Ledin, I. Chemical composition, digestibility, and voluntary feed intake of mango residues by sheep. Trop. Anim. Health Prod. 2013, 45, 665-669. [CrossRef] 
13. Silva, J.L.; Guim, A.; de Carvalho, F.F.R.; Mattos, C.W.; Menezes, D.R.; Coelho, M.C.S.C.; Garcia, D.A.; Pereira Neto, J.D.; Soares, L.F.P. Replacement of corn with mango meal for dairy goats. Rev. Colomb. Cien. Pec. 2016, 29, 178-187. [CrossRef]

14. Rao, D.S.; Ravi, A.; Yedukondalu, R. Inclusion of dried mango (Mangifera indica) peels in finisher rations of pigs on their performance. Indian J. Anim. Nutr. 2003, 20, 120-123.

15. Odunsi, A.A. Response of laying hens and growing broilers to the dietary inclusion of mango (Mangifera indica L.) seed kernel meal. Trop. Anim. Health Prod. 2005, 37, 139-150. [CrossRef] [PubMed]

16. Wadhwa, M.; Bakshi, M.P.S. Utilization of Fruit and Vegetable Wastes as Livestock Feed and as Substrates for Generation of Other Value-Added Products; Makkar, H.P.S., Ed.; FAO: Rome, Italy, 2013.

17. Prieto, C.; Aguilera, J.F.; Lara, L.; Fonolla, J. Protein and energy requirements for maintenance of indigenous Granadina goats. Br. J. Nutr. 1990, 63, 155-163. [CrossRef] [PubMed]

18. Molina-Alcaide, E.; Carro, M.D.; Roleda, M.Y.; Weisbjerg, M.R.; Lind, V.; Novoa-Garrido, M. In vitro ruminal fermentation and methane production of different seaweed species. Anim. Feed Sci. Technol. 2017, 228, 1-12. [CrossRef]

19. Goering, H.K.; Van Soest, P.J. Forage Fibre Analyses (Apparatus, Reagents, Procedures and Some Applications); Agriculture Handbook No. 379; Agricultural Research Service, USDA: Washington, DC, USA, 1970.

20. Van Soest, P.J.; Win, R.; Moor, L. Estimation of the true digestibility of forages by the in vitro digestion of cell walls. In Proceedings of the 10th International Grassland Congress, Helsinki, Finland, 7-16 July 1966; pp. 438-441.

21. Association of Official Analytical Chemists (AOAC). Official Methods of Analysis, 18th ed.; AOAC International: Gaithersburg, MD, USA, 2005.

22. Van Soest, P.J.; Robertson, J.B.; Lewis, B.A. Methods for dietary fiber, neutral detergent fiber and nonstarch polysaccharides in relation to animal nutrition. J. Dairy Sci. 1991, 74, 3583-3597. [CrossRef]

23. Isaac, M.D.; García, M.A.; Aguilera, J.F.; Molina-Alcaide, E. A comparative study of nutrient digestibility, kinetics of digestion and passage and rumen fermentation pattern in goats and sheep offered medium quality forages at the maintenance level of feeding. Arch. Tierernahr. 1994, 46, 37-50. [CrossRef]

24. Weatherburn, M.W. Phenol-hypochlorite reaction for determination of ammonia. Anal. Chem. 1967, 39, 971-974. [CrossRef]

25. SAS Institute. SAS/STAT ${ }^{\circledR}$ Users Guide, Version 9.3; SAS Institute Inc.: Cary, NC, USA, 2017.

26. Krishnamoorthy, U.; Soller, H.; Steingass, H.; Menke, K.H. A comparative study on rumen fermentation of energy supplements in vitro. J. Anim. Physiol. Anim. Nutr. 1991, 65, 28-35. [CrossRef]

27. France, J.; Dijkstra, J.; Dhanoa, M.S.; López, S.; Bannink, A. Estimating the extent of degradation of ruminant feeds from a description of their gas production profiles observed in vitro: Derivation of models and other mathematical considerations. Br. J. Nutr. 2000, 83, 143-150. [CrossRef] [PubMed]

28. Ranilla, M.J.; López, S.; Giráldez, F.J.; Valdés, C.; Carro, M.D. Comparative digestibility and digesta flow kinetics in two breeds of sheep. Anim. Sci. 1998, 66, 389-396. [CrossRef]

29. Berardini, N.; Knodler, M.; Schieber, A.; Carle, R. Utilization of mango peels as a source of pectin and polyphenolics. Innov. Food Sci. Emerg. Technol. 2005, 6, 442-452. [CrossRef]

30. Negesse, T.; Makkar, H.P.S.; Becker, K. Nutritive value of some non-conventional feed resources of Ethiopia determined by chemical analyses and an in vitro gas method. Anim. Feed Sci. Technol. 2009, 154, $204-217$. [CrossRef]

31. Pearson, D. Seasonal English market variations in the composition of South African and Israeli avocados. J. Sci. Food Agric. 1975, 26, 207-213. [CrossRef]

32. Slater, G.G.; Shankman, S.; Shepherd, J.S.; Alfin-Slater, R.B. Seasonal variation in the composition of Californian avocado. J. Agric. Food Chem. 1975, 23, 468-474. [CrossRef]

33. Geerkens, C.H.; Nagel, A.; Just, K.M.; Miller-Rostek, P.; Kammerer, D.R.; Schweiggert, R.M.; Carle, R. Mango pectin quality as influenced by cultivar, ripeness, peel particle size, blanching, drying, and irradiation. Food Hydrocoll. 2015, 51, 241-251. [CrossRef]

34. NRC (National Research Council). Nutrient Requirements of Dairy Cattle, 7th ed.; National Academy of Sciences: Washington, DC, USA, 2001.

35. FEDNA (Federación Española para el Desarrollo de la Nutrición Animal). Available online: http://www. fundacionfedna.org/ (accessed on 6 November 2020). 
36. Menke, K.H.; Steingass, H. Estimation of energetic feed value obtained from chemical analysis and in vitro gas production. Anim. Res. Dev. 1988, 28, 7-55.

37. Grant, L.J.; Mikkelsen, D.; Ouwerkerk, D.; Klieve, A.V.; Gidley, M.J.; Williams, B.A. Whole fruit pulp (mango) and a soluble fibre (pectin) impact bacterial diversity and abundance differently within the porcine large intestine. Bioact. Carbohydr. Diet. Fibre 2019, 19, 100192. [CrossRef]

38. Marcos, C.N.; García-Rebollar, P.; de Blas, C.; Carro, M.D. Variability in chemical composition and in vitro ruminal fermentation of olive cake in Spain. Animals 2019, 9, 109. [CrossRef]

39. Danielsson, R.; Ramin, M.; Bertilsson, J.; Lund, P.; Huhtanen, P. Evaluation of a gas in vitro system for predicting methane production in vivo. J. Dairy Sci. 2017, 100, 8881-8894. [CrossRef] [PubMed]

40. Maia, M.R.; Chaudhary, L.C.; Figueres, L.; Wallace, R.J. Metabolism of polyunsaturated fatty acids and their toxicity to the microflora of the rumen. Antonie Van Leeuwenhoek 2007, 91, 303-314. [CrossRef] [PubMed]

41. Krumreich, F.D.; Borges, C.D.; Mendonça, C.R.B.; Jansen-Alves, C.; Zambiazi, R.C. Bioactive compounds and quality parameters of avocado oil obtained by different processes. Food Chem. 2018, 257, 376-381. [CrossRef] [PubMed]

42. Skenjana, A.; van Ryssen, J.B.J.; van Niekerk, W.A. In vitro digestibility and in situ degradability of avocado meal and macadamia waste products in sheep. S. Afr. J. Anim. Sci. 2006, 36, 78-81.

43. Sanon, H.; Kanwe, A. Valorisation of mango peels and seed kernels in animal feeding: Nutritive value and voluntary feed intake by sheep. Adv. Anim. Biosci. 2010, 1, 445-446. [CrossRef]

44. Naveen, Z.; Prasad, J.R.; Rao, Z.P. Chemical composition and in vitro dry matter digestibility of some fruit wastes. Tamilnadu J. Vet. Anim. Sci. 2007, 3, 1-3.

45. Pereira, L.G.R.; Barreiros, D.C.; Oliveira, L.S.; Ferreira, A.L.; Mauricio, R.M.; Azevêdo, J.A.G.; Figueiredo, M.P.; Sousa, L.F.; da Cruz, P.G. Chemical composition and ruminal fermentation kinetics of fruit by-products in south Bahia. Livest. Res. Rural Dev. 2008, 20,1-13.

46. Van Soest, P.J. Nutritional Ecology of the Ruminant, 2nd ed.; Cornell University Press: Ithaca, NY, USA, 1994.

47. De Evan, T.; Vintimilla, A.; Molina-Alcaide, E.; Ranilla, M.J.; Carro, M.D. Potential of Recycling Cauliflower and Romanesco Wastes in Ruminant Feeding: In Vitro Studies. Animals 2020, 10, 1247. [CrossRef]

48. Satter, L.D.; Slyter, L.L. Effect of ammonia concentration on rumen microbial protein production in vitro. Br. J. Nutr. 1974, 32, 199-208. [CrossRef]

49. Jimenez, P.; Garcia, P.; Quitral, V.; Vasquez, K.; Parra-Ruiz, C.; Reyes-Farias, M.; Garcia-Diaz, D.F.; Robert, P.; Encina, C.; Soto-Covasich, J. Pulp, Leaf, Peel and Seed of Avocado Fruit: A Review of Bioactive Compounds and Healthy Benefits. Food Rev. Int. 2020. [CrossRef]

50. Patra, A.K.; Saxena, J. Exploitation of dietary tannins to improve rumen metabolism and ruminant nutrition. J. Sci. Food Agric. 2011, 91, 24-37. [CrossRef] [PubMed]

Publisher's Note: MDPI stays neutral with regard to jurisdictional claims in published maps and institutional affiliations.

(C) 2020 by the authors. Licensee MDPI, Basel, Switzerland. This article is an open access article distributed under the terms and conditions of the Creative Commons Attribution (CC BY) license (http://creativecommons.org/licenses/by/4.0/). 